Medicinae. Both will be published by the Pergamon Press, Oxford. The first formal meeting of the Academy will be held during September 6-7, 1964, at the University of Basle, with a symposium on "Materia Medica in the Sixteenth Century", the proceedings of which will be published in full. The first of many useful projects which the Academy hopes to undertake is a world survey of resources and facilities for research in the history of medicine. It is hoped that universities and societies will co-operate in making this survey as comprehensive as possible.

\section{Registrar General's Quarterly Return for England and Wales}

THE Registrar General's Quarterly Return for the second quarter of 1963 continues to show a high level of births (General Register Office. The Registrar General's Quarterly Return for England and Wales-Births, Deaths and Marriages; Infectious Diseases; Weather; Population Estimates, quarter ended 30th June, 1963. No. 458, 2nd Quarter, 1963. Pp. 24. London: H.M.S.O. $2 s .6 d$. net). If the distribution by quarters over the past ten years remains the same, the number of births in 1963 is likely to be 858,000 as against 841,000 in 1962 , a rise of 2 per cent. Appendix $C$ of the Return shows the population enumerated at the 1961 Census broken down by sex and age; males now outnumber females in the population below the age of thirty-four, and there are 1,013 males per 1,000 females in the age groups $20-34$, in which the bulk of marriages take place. The abridged life table for 1960-62 indicates that the expectation of life at birth is now six years higher for males than for females, 74.0 as against $68 \cdot 1$ years, and with the present masculinity ratio at birth would lead to a male excess at all ages up to 55 .

\section{The Agricultural Research Service}

UNDER the title of the Agricultural Research Service. the Agricultural Research Council has issued a booklet describing the scope of the agricultural research service in Great Britain and the ways in which the Council endeavours to ensure that, in this field, manpower and resources are used to the best advantage ( $\mathrm{Pp}$. iv +74 . London: Agricultural Research Council. Obtainable from H.M.S.O.: 1963. 5s.). The booklet details the scope, development and constitution of the Council and also gives information on State-aided and Council institutions, visiting groups, units, problems for research, grants, funds and schemes for postgraduate scholarships and fellowships. There are short descriptive articles dealing with eareers in agricultural research and the Commonwealth Agricultural Bureaux. The greater part of the booklet deals with the agricultural research institutes, which are listed in order of establishment. Information can be gleaned on the names of the directors, departments within the institutes, and the individuals concerned, along with a short history. The Council employs nearly 1,000 persons in the scientifie officer class in addition to about 700 in the experimental officer class. The publication, as such, represents a useful addition to the directories of British science. However, its value would have been greatly enhanced if an index had been supplied and if details of research work undertaken by each division of the institutes had been briefly outlined as, for example, has been done for the Pedology Department of the Macaulay Institute for Soil Research.

\section{Automation and Library Services}

IN the Library Association Prize Essay, 1963, "The Role of Libraries in a Push-button World", published in the Library Association Record $(65,403$; November 1963), Mr. D. J. Simpson attempts to forecast the part the librarian can play in a world in which automation, the computer and operational research play an increasing part. Whilo the expert in the new methods and techniques will become more and more important and use of mechanical aids will spread increasingly into the library itself, Mr. Simpson believes that the function of the librarian will also become more important, particularly in assisting experts in one field to get in touch with experts in another, and in keeping those responsible for decisions well informed. He refers particularly to the opportunities of the university librarian and those of other institutions of higher education, to the need for co-operation by the teaching staff in compiling appropriate and authoritative reading lists, for example, and also to the way in which the librarian can help ordinary citizens to understand the world in which they live and to play an informed part in it, as well as to cope with their new working environment more efficiently. Mr. Simpson sees the need for rapid. improvement in the quality and scale of library services and does not overlook their contribution to the creative use of leisure. His essential emphasis is on the personal and human contribution of the librarian, and this contrasts somewhat with Mr. B. C. Vickery's emphasis in a paper, "Scientific Information: Problems and Prospects", contributed to the current issue of Minerva $(2,21 ; 1963)$, which lies rather on the mechanical side. Mr. Vickery's scope is, as his title indicates, rather more restricted than Mr. Simpson's, though both begin by considering essentially the same problem. Mr. Vickery considers more particularly the special needs of the scientist or technologist, and while he recognizes that discussion and personal contact play a part he is concerned mainly with accelerating the process of communication. Here he contributes a well-balanced and critical survey of developments and possibilities which fully recognizes the importance of choosing the tool for the job, though without indicating a precise means of solving the problems beyond. the need for more research and imaginative thinking.

\section{Chemistry of the Earth's Crust}

To celebrate the hundredth anniversary of the birth of the pioneer geochemist, V. I. Vernadsky. an international conference on the chemistry of the Earth's crust was held in the Vernadsky Institute in Moscow on March 14, 1963. The first of two volumes of the proceedings of this meeting, which has just been published in Russian (Khimiya Zemnoi Kory. 1. Pp. 432. Academy of Sciences, Moscow, 1963. $21 r .71 k$.), comprises 29 papers contributed by Russian scientists. The second volume will have an international authorship. The range of topics covered is too wide to be enumerated fully in a brief notice, but passing mention may ke made of reports of researches on rocks elaimed to be the oldest in the Earth's crust (norites, pyroxenites and peridotites of the Kola-Karelian and Aldan shields, dated by potassium-argon methods at 4,000-6,500 $\mathrm{m} \mathrm{y.)}$; on the geochemistry and mineralogy of the sandstones of the Russian platform. with detailed analyses of more than 400 samples composited from more than 6,000 specimens, from Sinien to Recent in age; on the composition and mass of the load carried by Russian rivers; on the chemistry of the deep intra-stratal brines encountered by borings at depths of up to $3 \mathrm{~km}$ in the Irkutsk region, below the Cambrian evaporite deposits; on the application of potassium-argon age determinations to marine geology and palæogeography; on the radioactivity of ocean sediments; on the organic compounds in the eruptive (alkalic) and metamorphic rocks of the Kola peninsula; and on the geochronological variation of sulphur isotope ratios in oil and gas. Other papers deal with many aspects of the chemistry of igneous, sedimentary and metamorphic rocks. The whole symposium presents a balanced picture of the most modern trends in Russian geochemical investigations, and it is a fitting tribute to the founder of the science.

\section{Humic Substances}

AN article by P. Dubach and N. C. Mehta on "The Chemistry of Soil Humic Substances" in Soils and Fertilizers (26, No. 5. Commonwealth Bureau of Soils, 1963) 